\title{
KONTROL DIRI, PENDIDIKAN PENGELOLAAN KEUANGAN KELUARGA, PENGETAHUAN INKLUSI KEUANGAN SISWA PENGARUHNYA TERHADAP PERILAKU MENABUNG SISWA SMK SE KOTA KEDIRI
}

\author{
Meta Ardiana, Pascasarjana Unesa \\ metamatamega@rocketmail.com
}

\begin{abstract}
ABSTRAK
Penelitian ini bertujuan untuk menganalisis pengaruh kontrol diri, pendidikan pengelolaan keuangan keluarga, pengetahuan inklusi keuangan siswa secara parsial maupun simultan. Populasi dalam penelitian ini adalah siswa SMK jurusan Akuntansi, dan Perbankan se Kota Kediri sebanyak 477 dengan jumlah sampel sebanyak 211 siswa. Adapun teknik pengumpulan data yaitu angket dan dokumentasi. Metode analisis menggunakan teknik regresi linier berganda. Hasil penelitian menunjukkan bahwa kontrol diri, pendidikan pengelolaan keuangan keluarga, pengetahuan inklusi keuangan siswa secara parsial berpengaruh signifikan positif terhadap perilaku menabung siswa SMK se Kota Kediri. Kontrol diri, pendidikan pengelolaan keuangan keluarga, pengetahuan inklusi keuangan siswa secara simultan berpengaruh signifikan positif terhadap perilaku menabung siswa SMK se Kota Kediri.
\end{abstract}

Kata Kunci : Kontrol diri, pendidikan pengelolaan keuangan keluarga, pengetahuan inklusi keuangan siswa, perilaku menabung.

\begin{abstract}
This study aimed (1) to analyze the influence of self-control on the savings behaviors of students, (2) analyze the influence of family financial management education to saving behavior, (3) analyze the effect of students knowledge of financial inclusion on the saving behaviors of students, (4) analyze the influence of self control, family financial management education, students knowledge of financial inclusion on saving behavior of students SMK in Kediri. The population in this study is accounting students and banking students a total of 477 and a total sample of 211 students. The data collection techniques used were questionnaire and document. Analyze methode using multiple linear regression technique. The result showed that the self control, family financial management education, students knowledge of financial inclusion partially has positive significant effect on saving behaviors student SMK in Kediri. Self control, family financial management education, students knowledge of financial inclusion Simultaneously have positive significant effect on saving behaviors student SMK in Kediri.
\end{abstract}

Keywords: self control, family financial management education, students knowledge of financial inclusion, saving behaviors. 


\section{PENDAHULUAN}

Kesadaran menabung dikalangan masyarakat dirasa masih rendah, perilaku masyarakat dalam menabung selama ini hanya dilakukan ketika terdapat kelebihan pendapatan setelah konsumsi tercukupi. Bank Indonesia (BI) mencatat masih minimnya masyarakat Indonesia yang terakses system keuangan, yakni lebih dari setengah dari total rumah tangga di Indonesia belum mempunyai tabungan sama sekali. survey World Bank tahun 2010 yang menyebutkan, di Indonesia akses terhadap jasa keuangan formal hanya tersedia bagi setengah penduduk Indonesia, $32 \%$ dari penduduk Indonesia bahkan tidak memiliki tabungan baik di sektor formal maupun informal dan masuk ke dalam kategori financially excluded.

Apabila kita telaah lagi peranan menabung dalam pertumbuhan ekonomi suatu negara ini sangat penting, Keynes (1935) menyatakan kecepatan pertumbuhan ekonomi suatu negara tergantung pada kemampuan menabung, semakin tinggi tingkat tabungan akan mendorong tingkat investasi dan akan merangsang pertumbuhan ekonomi. Begitu pentingnya peranan menabung, maka pembiasaan menabung perlu ditanamkan pada anak dari kecil sampai dewasa, khususnya pada fase remaja, dimana pada masa remaja siswa mulai diberi kepercayaan mengelola keuangannya secara mandiri.

Tingginya tingkat konsumtif yang cenderung pada pola hidup boros, dikalangan remaja merupakan salah satu fenomena yang banyak terjadi terutama remaja yang bersekolah dan tinggal di daerah kota. Masalah ini juga menimpa sebagian besar remaja di Kota Kediri, khususnya para remaja yang duduk dibangku sekolah menengah atas. Hal ini didukung oleh kondisi Kota Kediri, meskipun kota kecil tetapi sangat terfasilitasi dengan pusat-pusat perbelanjaan, ditunjukkan dengan mudah ditemukan cafe, mall-mall, distro, dan factory outlet. Tempat itulah yang kemudian menjadi simbol pergaulan remaja Kota Kediri. Banyak remaja yang rela mengeluarkan uang saku untuk membelanjakan segala keperluannya dengan tidak memikirkan terlebih dahulu apa manfaat dari barang tersebut karena kebanyakan dari mereka belum memiliki rasionalitas ekonomi yang baik, mereka sering membeli barang hanya karena keinginan semata bukan karena kebutuhan, Hal tersebut mengilustrasikan kontrol diri remaja kediri masih kurang, masalah tersebut juga dialami oleh siswa SMK di Kediri.

Pendidikan pengelolaan keuangan yang baik akan membiasakan anak-anak menjadi pribadi yang memiliki literasi keuangan yang baik. Kebanyakan siswa SMK di Kediri merupakan anak kost karena berasal dari luar kota kediri, sehingga mereka mulai diberikan kepercayaan orang tua mereka untuk mengelola keuangannya secara mandiri. Penelitian yang dilakukan Firmansyah (2014) menunjukkan hasil bahwa dukungan orang tua dan pengalaman orang tua memberikan pengaruh terhadap perilaku menabung siswa. Pengetahuan inklusi keuangan merupakan pengetahuan tentang pembiayaan inklusif, dengan tujuan utama memberikan berbagai layanan keuangan. Layanan keuangan ini bisa berupa kredit permodalan, tabungan, asuransi, serta layanan transfer keuangan (Wahid, 2014:15). Pendidikan di SMK khususnya untuk jurusan Akuntansi dan Perbankan sudah mendapatkan materi tentang inklusi keuangan. Akan tetapi sering terjadi meskipun sudah mendapatkan pengetahuan akan tetapi kebanyakan siswa belum bisa mengaplikasikan dalam kehidupan nyata. Sebagai seorang 
pelajar, mereka sering lupa bahwa mereka akan tumbuh sedangkan mereka tidak mempersiapkan diri untuk masa depan mereka, terutama dalam hal materi. Membudayakan menabung memang harus diterapkan sejak dini, peran keluarga menjadi sangat penting mengingat pendidikan keluarga merupakan pendidikan yang pertama dan utama. Siswa SMK adalah salah satu komponen masyarakat yang jumlahnya cukup besar dan akan memberikan pengaruh besar terhadap perekonomian, siswa SMK dididik menjadi tenaga kerja terampil tingkat menengah, karena di kemudian hari setelah lulus akan memasuki dunia kerja dan mulai mandiri termasuk dalam pengelolaan keuangannya (Nababan, 2011). Siswa pasti menempuh masa sekolah untuk menyelesaikan studinya. Masa sekolah merupakan masa dimana siswa harus mau untuk belajar mandiri dalam berbagai aspek kehidupan dan harus bertanggung jawab atas segala sesuatu yang diputuskan.

Dari hasil observari yang telah dilakukan, terdapat kendala bagi siswa SMK di Kota Kediri dalam memprioritaskan kebutuhan. Salah satu kendala bagi siswa tersebut yaitu kendala keuangan. Siswa memiliki masalah keuangan yang kompleks karena sebagian besar siswa adalah anak kost yang berasal dari kabupaten sekitar Kota Kediri, dan belum memiliki pendapatan, cadangan dana juga terbatas untuk digunakaan setiap bulannya. Masalah lain yang dihadapi bisa karena keterlambatan uang kiriman dari orang tua, atau uang bulanan habis sebelum waktunya, yang bisa disebabkan oleh kebutuhan yang tidak terduga, ataupun disebabkan pengelolaan keuangan pribadi yang salah (tidak adanya penganggaran), serta gaya hidup dan pola konsumsi boros.

Kendala keuangan tersebut, secara langsung maupun tidak langsung akan berdampak terhadap salah satu pola keuangan siswa yaitu dalam hal menabung. Selain itu kendala siswa dalam menabung disebabkan karena minat dan antusias siswa untuk menabung belum besar. Hal tersebut terjadi karena pada umumnya siswa belum termotivasi dalam melakukan kegiatan menabung. Faktanya dari 3 SMK di Kediri yang diteliti sudah memberikan fasilitas untuk membiasakan siswa dalam menabung selain melalui proses pembelajaran, juga disediakan Laboratorium Bank Mini dimana siswa biasanya praktik kerja intern secara bergiliran, namun kurang dari $40 \%$ saja yang aktif melakukan kegiatan menabung, padahal masing-masing siswa terdaftar menjadi nasabah.

Gottefredson \& Ralston (dalam Hoyri, 2014) mendefinisikan kontrol diri sebagai derajat kemudahan seseorang terkena serangan godaan sesaat. Selanjutnya Gottfredson menyatakan orang yang memiliki kontrol diri yang rendah adalah orang-orang yang memiliki orientasi here and now, lebih memilih menyelesaikan sesuatu secara fisik dari pada mengandalkan kognitif, senang dalam aktivitas berbahaya, kurang sensitif pada kebutuhan orang lain, lebih memilih jalan pintas dibanding dengan hal-hal yang kompleks, serta memili toleransi yang rendah terhadap sumber frustasi. Lebih Lanjut Gottefredson \& Ralston (dalam Hoyri, 2013) menyatakan empat aspek yang menjelaskan ciri orang yang memiliki kontrol diri yang rendah yaitu Impulsiveness, Phsycal Activity, Risk and Seeking, Self centeredness, selanjutnya akan diuraikan secara singkat sebagai berikut : 1). Impulsiveness: Konsep ini mengacu pada seseorang yang tidak mempertim bangkan konsekuensi negatif dari perbuatan yang akan dilakukannya. Mereka memiliki orientasi here and now dan gampang tegoda untuk sesuatu yang menyenangkan. 2) Physical Activity : Konsep ini menjelaskan individu dengan 
kontrol diri yang rendah lebih memilih kegiatan yang melibatkan aktifitas fisik dari pada aktivitas yang melibatkan pemikiran. 3). Risk And Seeking : Konsep ini menjelaskan bahwa individu dengan kontrol diri yang rendah suka terlibat dalam aktifitas-aktifitas fisik yang beresiko, membangkitkan dan menegangkan. 4). Selfcenteredness : Konsep ini menjelaskan individu dengan kontrol diri yang rendah cenderung mementingkan diri sendiri, kurang sensitif terhadap penderitaan dan kebutuhan orang lain, mereka sering tidak ramah, atau cenderung kurang peduli dalam pembinaan hubungan dengan orang lain.

Sedangkan menurut Ghufron (2010) Kontrol diri dengan sebutan kontrol personal perilaku (behavior control), kontrol kognitif (cognitive control), dan mengontrol keputusan (decisional control). Kontrol Perilaku (Behavior control) Kontrol perilaku merupakan kesiapan tersedianya suatu respons yang dapat secara langsung mempengaruhi atau memodifikasi suatu keadaan yang tidak menyenangkan. Firmansyah (2014) menyatakan kemampuan mengontrol perilaku diperinci menjadi komponen, yaitu mengatur pelaksanaan regulated administration) dan kemampuan memodifikasi stimulus. Kemampuan mengatur pelaksanaan merupakan kemampuan individu untuk menentukan siapa yang mengendalikan situasi atau keadaan. Apakah dirinya sendiri atau aturan perilaku, dengan menggunakan kemampuan dirinya dan bila tidak mampu akan menggunakan sumber eksternal. Kemampuan untuk mengetahui bagaimana dan kapan suatu stimulus yang tidak dikehendaki dihadapi. Ada beberapa cara yang dapat digunakan, yaitu mencegah atau menjauhi stimulus yang sedang berlangsung, menghentikan stimulus sebelum waktunya berakhir, dan membantu intensitasnya. Averil (1973) menyatakan kontrol perilaku didasarkan oleh pengalaman masa lalu dan perkiraan dari individu mengenai seberapa sulit atau mudahnya melakukan suatu aktivitas sehingga memberikan dampak yang positif bagi diri individu. 2) Kontrol kognitif (Cognitive control) : kontrol kognitif merupakan kemampuan individu dalam mengolah informasi yang tidak diinginkan dengan cara menginterpretasi, menilai, atau menghubungkan suatu kejadian dalam suatu kerangka kognitif sebagai adaptasi psikologis atau mengurangi tekanan. Aspek ini terdiri atas dua komponen, yaitu memperoleh informasi (information gain) dan melakukan penilaian (appraisal). Dengan informasi yang dimiliki oleh individu mengenai suatu keadaan yang tidak menyenangkan, individu dapat mengantisipasi keadaan tersebut dengan berbagai pertimbangan. Melakukan penilaian berarti individu berusaha menilai dan menafsirkan suatu keadaan atau peristiwa dengan cara memperhatikan segi-segi positif secara subjektif. 3) Mengontrol keputusan (Decisional control) engontrol keputusan merupakan kemampuan seseorang untuk memilih hasil atau suatu tindakan berdasarkan pada sesuatu yang diyakini atau yang disetujuinya. Kontrol diri dalam menentukan pilihan akan berfungsi, baik dengan adanya suatu kesempatan, kebebasan, atau kemungkinan pada diri individu untuk memilih berbagai kemungkinan tindakan (Ghufron, 2010: 31).

Berdasarkan beberapa teori ahli tersebut dapat disimpulkan bahwa kontrol diri berkaitan dengan bagaimana individu mengendalikan emosi serta dorongandorongan dari dalam dirinya. Karena individu yang memiliki kontrol diri yang rendah cenderung mudah untuk terlibat dengan hal-hal yang bersifat negatif, misal yang sering terjadi pada remaja tawuran, perilaku konsumtif, dan pergaulan bebas. Kontrol diri melibatkan kemampuan untuk memanipulasi diri baik untuk 
mengurangi maupun meningkatkan perilakunya. Baik mengontrol dalam hal keputusan, tindakan, maupun secara kognitif.

. Tokoh lain yang juga memberikan definisi kontrol diri antara lain Averil (1973) memberikan definisi kontrol diri dengan membedakannya kedalam tiga jenis kontrol diri yaitu kontrol perilaku, kontrol kognitif dan mengontrol keputusan. Kontrol perilaku dedifinisikan sebagai kemampuan untuk bertindak yang dapat secara langsung mempengaruhi atau memodifikasi suatu keadaan yang tidak menyenangkan. Kontrol kognitif merupakan kemampuan individu dalam mengolah informasi yang tidak diinginkan dengan cara menginterprestasi, menilai, atau menghubungkan suatu kejadian-kejadian dalam suatu kerangka kongnitif sebagai adaptasi psikologi atau mengurangi tekanan. Kemudian mengontrol keputusan didefinisikan sebagai kemapuan seseorang untuk memilih hasil atau suatu tindakan berdasarkan pada sesuatu yang diyakini atau disetujuinya. Berdasarkan beberapa teori ahli tersebut dapat disimpulkan bahwa kontrol diri berkaitan dengan bagaimana individu mengendalikan emosi serta dorongan-dorongan dari dalam dirinya.

Dari beberapa aspek yang tercakup dalam pendidikan anak di keluarga, aspek keuangan memiliki pengaruh yang besar dalam proses pendewasaan anak menuju kehidupan yang mandiri dan sejahtera. Sebagian aktivitas manusia tidak terlepas dari masalah keuangan. Namun masih banyak keluarga yang kurang menyadari pentingnya pendidikan keuangan bagi anak. Dari berbagai aspek yang tercakup dalam pendidikan anak dalam keluarga, aspek pendidikan keuangan memilik pengaruh yang besar pendewasaan anak menuju kehidupan yang mandir. Aspek pendidikan keuangan dianggap sebagai aspek penting dan terdapat anggapan bila aspek tersebut telah tertanam dengan baik maka dengan sendirinya anak dapat mengaplikasikan sikap dan perilaku keuangan dengan baik. Penelitian yang dilakukan Firmansyah (2014) dengan judul The Influence of Family Backgrounds toward Student Saving Behavior menunjukkan hasil bahwa terdapat korelasi tinggi antara dorongan orang tua dan pengalaman orang tua terhadap perilaku menabung siswa.Penelitian yang dilakukan Salikin,dkk pada tahun 2012 dengan judul "Students Saving Attitude: Does Parent's Background Matter?". Dari penelitian tersebut diketahui bahwa latar belakang orang tua berpengaruh terhadap perilaku menabung mahasiswa. Perilaku menabung mahasiswa bergantung pada status sosial ekonomi orang tua maupun pendidikan pengelolaan keuangan yang diberikan oleh keluarga.

Penanaman kesadaran kepada seorang anak akan pentingnya menabung, tidaklah cukup dilakukan hanya dengan menyuruh dan memerintah. Akan tetapi, proses yang dibutuhkan adalah adanya sebuah arahan, adanya panutan yang kemudian dipraktekan dan dilakukan implementasi secara langsung agar anak dapat merasakan perilaku menabung dan nantinya akan menjadi sebuah kebiasaan.Menurut Owen (2003) berpendapat bahwa untuk melatih ketrampilan mengelola keuangan dengan baik, paling tidak anak harus dilatih dalam hal menabung, mengelola uang saku, melakukan pekerjaan ringan di luar rumah, berderma dan berinvestasi. Menurut Wahyono (2001) menyatakan proses pendidikan ekonomi di lingkungan keluarga, seperti halnya untuk aspek-aspek lain, biasanya tidak terjadwal sehingga keberlangsungannya terjadi setiap saat dan bersifat insidental. 
Orang tua merupakan agen sosialisasi utama dalam proses belajar anak mengenai uang dan proses pengembangan perilaku pengelolaan keuangan yanga dilakukan dengan tidak sengaja (melalui pengamatan atau partisipasi langsung) dan secara sengaja melalui pelajaran yang diberikan oleh keluarga. Orang tua dapat berperan langsung dan dapat menjadi contoh panutan dalam perkembangan keuangan anak mereka. Pendidikan pengelolaan keuangan di keluarga harus menyadari bahwa pentingnya mengajarkan perilaku finansial dalam diri anak misalnya memberikan uang saku kepada anak.

Memberikan uang saku kepada anak menunjukkan kepercayaan orang tua kepada anak. Memberikan uang saku kepada anak melatih tanggung jawab finansial untuk mengatur keuangan mereka sendiri seperti membelanjakan dan menabung. Dengan memberikan pendidikan pengelolaan keuangan maka ada beberapa hal yang positif terkait dengan membelanjakan, menabung, maupun mengivestasikan uang dengan benar lermitte (dalam Susanti, 2013).

Wahyono (2001) menyatakan bahwa proses pendidikan keuangan di keluarga, seperti halnya untuk aspek-aspek lain dan biasanya tidak terjadwal sehingga berlangsung terjadi setiap saat dan bersifat insidental, maka proses keteladanan dan sikap keseharian orang tua serta intensitas komunikasi antara anak dan orang tua dalam kehidupan keluarga memiliki peran penting bagi pendidikan keuangan anak.

Pendidikan keuangan di keluarga dititikberatkan pada pemahaman tentang nilai uang untuk mengatur pemanfaatan uang. Seorang ahli kecerdasan financial pada anak, (Malmrose dalam Susanti, 2013) menyatakan bahwa untuk memiliki keterampilan mengelola keuangan dengan baik, paling tidak anak harus dilatih untuk rajin menabung, melakukan pembayaran secara mandiri atas kebutuhankebutuhan tambahan mereka, mengelola uang saku, melakukan pekerjaanpekrjaan rumah tertentu untuk mendapatkan ang saku tambahan, mencari pekerjaan ringan di luar rumah, berdema dan berinvestasi.

Berdasarkan pendapat diatas dapat disimpulkan bahwa salah satu lingkungan yang penting dalam perkembangan sikap dan mental selain pendidikan formal dan in-formal adalah keluarga (non-formal) yang notabene memiliki waktu yang lebih lama dalam berinteraksi dalam proses pengembangan dan pembentukan pola pikir anak itu sendiri yang mengacu pada norma-norma, nilainilai dan pengetahuan yang berkembang.

Dari pemaparan diatas untuk mengukur tingkat pengaruh pendidikan keuangan keluarga terhadap perilaku menabung diukur dengan: a). kebiasaan Menabung, b). melakukan pembayaran secara mandiri atas kebutuhan tambahan mereka, c) Mengelola uang saku (Owen,2003). Rata-rata peserta didik di Indonesia tidak memiliki akses pengetahuan tentang perilaku menabung dalam aktivitas mereka. Merujuk Survei Nielsen di sembilan kota di Indonesia menyebutkan sekitar 6\% pemilik rekening di Indonesia adalah kelompok umur 15-16 tahun, kira-kira pada rentang kelas tiga sekolah menengah pertama sampai awal kuliah. Survei tersebut membuktikan bahwa anak-anak pada usia remaja mempunyai kesadaran untuk menabung. Khususnya kalangan remaja yang belum menyadari kemungkinan ketidakpastian dimasa yang akan datang. Pengetahuan inklusi keuangan merupakan pengetahuan tentang pembiayaan inklusif, dengan tujuan utama memberikan berbagai layanan keuangan. Layanan keuangan ini bisa berupa kredit permodalan, tabungan, asuransi, serta layanan transfer keuangan 
(Wahid, 2014). Pendidikan di SMK khususnya untuk jurusan Akuntansi dan Perbankan sudah mendapatkan materi tentang inklusi keuangan. Terdapat beberapa definisi yang menjelaskan batasan serta karakteristik utama financial inklusion. Merujuk definisi PBB, terminologi inklusi keuangan mengacu kepada akses ke berbagai jasa keuangan, dengan biaya yang wajar, bagi orang-orang yang diangggap tidak bankable serta mereka yang menjelankan usaha di daerah perdesaan.

Rangarajan Committe mendefinisikan inklusi keuangan sebagai proses untuk memastikan kaum miskin atau masyarakat yang berpenghasilan rendah mendapat layanan keuangan. Adapun definisi ang lebih operasional ditawarkan oleh House of Commons Treasury Committe yang menyebutkan bahwa inklusi keuangan merupakan kemampuan seseorang dalam mengakses berbagai produk jasa keuangan yang terjangkau dan sesuai dengan kebutuhan. Kemampuan ini utamanya berkaitan dengan satu kompleks pemahaman yang meliputi financial awareness, pengetahuan tentang bank dan jaringan perbankan plus pengetahuan mengenai berbagai fasilitas yang disediakan dunia perbankan. Penelitian yang dilakukan oleh Brief (2012) yang berjudul Youth Financial Inclusion : Complementimg Financial Education with Account Access menyimpulkan bahwa sekolah dan lembaga keuangan merupakan mitra atau partner dalam menumbuhkan kebiasaan anak dalam menabung. Pengetahuan inklusi keuangan dan pengalaman sejak dini tentang perbankan dapat membantu anak membangun kebiasaan keuangan yang baik, melatih kontrol diri dan memiliki rencana masa depan.

Merujuk pada penelitian yang dilakukan oleh Nurasiyah (2010) menyatakan bahwa dari siswa SMA di Kota Bandung menyebutkan bahwa ratarata pengeluaran yang dikeluarkan selama satu bulan dari uang sakunya yaitu $61 \%$ digunakan untuk jajan (makanan-minuman), 21,26 \% digunakan untuk kepentingan pribadi yang bersifat kesenangan. (Isi Pulsa HP, jalan-jalan nonton di bioskop dan membeli barang-barang baru) 16,23\% digunakan untuk belajar ongkos transport, beli buku alat tulis) sedangkan sisanya $0,88 \%$ digunakan untuk menabung. Dari penelitian diatas jelas bahwa kebanyakan pengeluaran yang dilakukan oleh siswa SMA di kota Bandung merupakan pengeluaran yang bersifat kesenangan saja. Dan hanya sekitar $16 \%$ yang digunakan untuk pengeluaran kebutuhan sekolah atau kebutuhan belajar yang merupakan investasi di masa yang akan datang. Dan dari penelitian tersebut kecenderungan siswa untuk menabung sangat kecil sekali.

Siswa SMK adalah salah satu komponen masyarakat yang jumlahnya cukup besar dan akan memberikan pengaruh besar terhadap perekonomian, siswa SMK dididik menjadi tenaga kerja terampil tingkat menengah, karena di kemudian hari setelah lulus akan memasuki dunia kerja dan mulai mandiri termasuk dalam pengelolaan keuangannya (Nababan, 2011). Siswa pasti menempuh masa sekolah untuk menyelesaikan studinya. Masa sekolah merupakan masa dimana siswa harus mau untuk belajar mandiri dalam berbagai aspek kehidupan dan harus bertanggung jawab atas segala sesuatu yang diputuskan.

Dari hasil observari yang telah dilakukan, terdapat kendala bagi siswa SMK di Kota Kediri dalam memprioritaskan kebutuhan. Salah satu kendala bagi siswa tersebut yaitu kendala keuangan. Siswa memiliki masalah keuangan yang kompleks karena sebagian besar siswa adalah anak kost yang berasal dari 
kabupaten sekitar Kota Kediri, dan belum memiliki pendapatan, cadangan dana juga terbatas untuk digunakaan setiap bulannya. Masalah lain yang dihadapi bisa karena keterlambatan uang kiriman dari orang tua, atau uang bulanan habis sebelum waktunya, yang bisa disebabkan oleh kebutuhan yang tidak terduga, ataupun disebabkan pengelolaan keuangan pribadi yang salah (tidak adanya penganggaran), serta gaya hidup dan pola konsumsi boros.

Kendala keuangan tersebut, secara langsung maupun tidak langsung akan berdampak terhadap salah satu pola keuangan siswa yaitu dalam hal menabung. Selain itu kendala siswa dalam menabung disebabkan karena minat dan antusias siswa untuk menabung belum besar. Hal tersebut terjadi karena pada umumnya siswa belum termotivasi dalam melakukan kegiatan menabung. Faktanya dari 3 SMK di Kediri yaitu SMK N 2 Kediri, SMK PGRI 2 Kediri, dan SMK Muhammadiyah Kediri sudah memberikan fasilitas untuk membiasakan siswa dalam menabung selain melalui proses pembelajaran, juga disediakan Laboratorium Bank Mini dimana siswa biasanya praktik kerja intern secara bergiliran, namun kurang dari $40 \%$ saja yang aktif melakukan kegiatan menabung, padahal masing-masing siswa terdaftar menjadi nasabah

Dengan demikian, tujuam dalam penelitian ini antara lain : a.) Menganalisis pengaruh kontrol diri, pendidikan pengelolaan keuangan keluarga, pengetahuan inklusi keuangan siswa pada perilaku menabung siswa SMK se Kota Kediri secara parsial; b.) Menganalisis pengaruh kontrol diri, pendidikan pengelolaan keuangan keluarga, pengetahuan inklusi keuangan siswa pada perilaku menabung siswa SMK se Kota Kediri secara parsial

\section{METODE PENELITIAN}

Pendekatan yang digunakan dalam penelitian ini adalah pendekatan kuantitatif. Variabel dalam penelitian ini adalah kontrol diri $\left(\mathrm{X}_{1}\right)$, pendidikan pengelolaan keuangan keluarga $\left(\mathrm{X}_{2}\right)$, dan pengetahuan inklusi keuangan siswa $\left(\mathrm{X}_{3}\right)$ sebagai variabel independen, sedangkan variabel dependen yaitu perilaku menabung (Y). Sedangkan Populasi dalam penelitian ini adalah seluruh peserta didik kelas XI program keahlian Akuntansi dan Perbankan Tahun Ajaran 2014/2015 yang berasal dari siswa SMK Se Kota Kediri, yakni SMK Negeri 2 Kediri, SMK PGRI 2 Kediri, dan SMK Muhamaddiyah. Jurusan tersebut dipiih dengan asumsi peserta didik telah mendapat materi pengelolaan dan pengetahuan keuangan terutama produk-produk bank (Financial Inklusion) pada materi dasardasar akuntansi dan perbankan yaitu sebanyak 447 siswa, dengan rincian sebagai pada tabel 1. Sedangkan sampel yang digunakan sebanyak 211 dengan menggunakan teknik pengambilan sampelnya proportional random sampling. Teknik pengumpulan data dalam penelitian ini yaitu menggunakan dokumentasi dan angket. Metode dokumentasi digunakan untuk memperoleh data penelitian di lapangan dalam bentuk kajian dokumentasi sekolah yang berupa jumlah siswa, profil sekolah dan susunan struktur sekolah. Angket atau kuesioner tertutup digunakan untuk mengumpulkan data primer atas variabel kontrol diri, pendidikan pengelolaan keuangan orang tua, pengetahuan inklusi keuangan siswa dan perilaku menabung siswa, sedangkan Pada penelitian ini teknik wawancara dilaksanakan pada Wakil Kurikulum dan pengelola Lab Bank Mini Pionir di SMK 
Negeri 2 Kediri. Teknik analisis data yang digunakan adalah regresi linier berganda dengan menggunakan rumus sebagai berikut :

$$
Y=\alpha+\beta_{1} X_{1}+\beta_{2} X_{2}+\beta_{3} X_{3}+e i
$$

Tabel 1

Jumlah Populasi Penelitian

\begin{tabular}{|c|c|c|c|}
\hline Nama Sekolah & $\begin{array}{l}\text { Program } \\
\text { Keahlian }\end{array}$ & Kelas & $\begin{array}{l}\text { Jumlah } \\
\text { Populasi }\end{array}$ \\
\hline \multirow{7}{*}{ SMK N 2 Kediri } & \multirow{5}{*}{ Akuntasi } & $\begin{array}{l}\text { XI AK } \\
1\end{array}$ & 35 \\
\hline & & $\begin{array}{l}\text { XI AK } \\
2\end{array}$ & 35 \\
\hline & & $\begin{array}{l}\text { XI AK } \\
3\end{array}$ & 35 \\
\hline & & $\begin{array}{l}\text { XI AK } \\
4\end{array}$ & 36 \\
\hline & & $\begin{array}{l}\text { XI AK } \\
5\end{array}$ & 35 \\
\hline & \multirow{2}{*}{ Perbankan } & XI PB 1 & 35 \\
\hline & & XI PB 2 & 35 \\
\hline \multirow{4}{*}{ SMK PGRI 2 Kediri } & \multirow{4}{*}{ Akuntansi } & $\begin{array}{l}\text { XI AK } \\
1\end{array}$ & 48 \\
\hline & & $\begin{array}{l}\text { XI AK } \\
2\end{array}$ & 48 \\
\hline & & $\begin{array}{l}\text { XI AK } \\
3\end{array}$ & 46 \\
\hline & & $\begin{array}{l}\text { XI AK } \\
4\end{array}$ & 49 \\
\hline \multirow[t]{2}{*}{$\begin{array}{c}\text { SMK } \\
\text { Muhammadiyah }\end{array}$} & Akuntansi & XI AK & 10 \\
\hline & \multicolumn{2}{|c|}{ Total } & 447 \\
\hline
\end{tabular}

Sumber: Data diolah, (2015)

Terdapat dua uji statistik yang digunakan dalam penelitian ini yaitu uji $\mathrm{t}$ dan uji F. Uji t digunakan untuk mengetahui ada atau tidaknya pengaruh kontrol diri $\left(\mathrm{X}_{1}\right)$. Pendidikan pengelolaan keuangan keluarga $\left(\mathrm{X}_{2}\right)$, pengetahuan inklusi keuangan siswa $\left(\mathrm{X}_{3}\right)$ secara parsial terhadap perilaku menabung siswa $(\mathrm{Y})$. Uji $\mathrm{F}$ digunakan untuk mengetahui ada atau tidaknya kontrol diri $\left(\mathrm{X}_{1}\right)$. Pendidikan pengelolaan keuangan keluarga $\left(\mathrm{X}_{2}\right)$, pengetahuan inklusi keuangan siswa $\left(\mathrm{X}_{3}\right)$ secara simultan terhadap perilaku menabung siswa $(\mathrm{Y})$.

\section{HASIL DAN PEMBAHASAN}

Berdasarkan hasil uji normalitas dengan menggunakan Kolmogrov-Smirnov di dapat nilai sebesar 0,659. Tingkat signifikansi tersebut lebih dari 5\% yang 
berarti residual mengikuti distribusi normal. Sehingga kontrol diri $\left(\mathrm{X}_{1}\right)$. Pendidikan pengelolaan keuangan keluarga $\left(\mathrm{X}_{2}\right)$, pengetahuan inklusi keuangan siswa (X3) dan perilaku menabung siswa (Y) berdistribusi normal.

Sedangkan untuk uji multikolinieritas untuk nilai tolerance kontrol diri $\left(\mathrm{X}_{1}\right)$ sebesar 0.408. Pendidikan pengelolaan keuangan keluarga $\left(\mathrm{X}_{2}\right)$ sebesar 0.898, pengetahuan inklusi keuangan siswa (X3) sebesar 0.432. Dan untuk nilai VIF tolerance kontrol diri $\left(\mathrm{X}_{1}\right)$ sebesar 2.454. Pendidikan pengelolaan keuangan keluarga $\left(\mathrm{X}_{2}\right)$ sebesar 1.113, pengetahuan inklusi keuangan siswa (X3) sebesar 2.313. dari ketiga variabel bebas mempunyai nilai $\mathrm{VIF}<10$ / kurang dari 10 , artinya ketiga variabel bebas (independent) yaitu kontrol diri, pendidikan pengelolaan keuangan keluarga, dan pengetahuan inklusi keuangan siswa tidak terdapat hubungan multikolinearitas sehingga dapat digunakan untuk memprediksi perilaku menabung siswa SMK se Kota Kediri. Adapun hasil pengolahan data dengan metode regresi linier bergada sebagai berikut :

$$
Y=22.891+0.592 X_{1}+0.866 X_{2}+0.525 X_{3}+e i
$$

Dari persamaan regresi linier berganda dapat dijelaskan : 1.) Konstanta $(\alpha)$ sebesar 22.891 artinya bahwa dengan menganggap semua variabel bebas sama dengan 0, maka perilaku menabung dalam kondisi positif dengan nilai 22.891; 2.) Koefisien regresi kontrol diri intrinsik (b1) sebesar 0.592 artinya bahwa setiap peningkatan satu persen kontrol diri pada perilaku menabung akan mengalami peningkatan sebesar 0.592 persen. Dengan asumsi variabel pendidikan pengelolaan keuangan keluarga, dan pengetahuan inklusi keuangan siswa konstan. Nilai koefisien regresi menunjukkan nilai yang positif, dalam arti jika variabel kontrol diri naik 1\%, maka akan berpengaruh pada kenaikan variabel perilaku menabung sebesar $0.592 \%$. Sebaliknya jika variabel kontrol diri turun $1 \%$ akan mengakibarkan variabel perilaku menabung mengalami penurunan sebesar $0.592 \%$; 3.) Koefisien regresi variabel pendidikan pengelolaan keuangan keluarga (b2) sebesar 0.866 artinya bahwa setiap peningkatan satu persen pendidikan pengelolaan keuangan keluarga maka perilaku menabung akan mengalami peningkatan sebesar 0.866 persen. Dalam hal ini faktor lain yang mempengaruhi perilaku menabung dianggap tetap; 4.) Koefisien regresi variabel pengetahuan inklusi keuangan siswa (b3) sebesar 0.525 artinya bahwa setiap peningkatan satu persen pengetahuan inklusi keuangan siswa maka perilaku menabung akan mengalami peningkatan sebesar 0.525 persen. Dalam hal ini faktor lain yang mempengaruhi perilaku menabung dianggap tetap.

Uji $t$ statistik digunakan untuk mengetahui pengaruh masing-masing variabel bebas terhadap variabel terikat yaitu pengaruh secara parsial kontrol diri, pendidikan pengelolaan keuangan keluarga, pengetahuan inklusi keuangan siswa terhadap perilaku menabung siswa SMK se Kota Kediri. Adapun hasil uji t disajikan pada tabel 2.

Dari tabel tersebut dapat dilihat bahwa nilai signifikansi masing-masing variabel bebas sebagai berikut: a). Variabel $\mathrm{X}_{1}$ kontrol diri memiliki thitung $=$ $21,496>1,971$ dan signifikansi $(\mathrm{sig})=0,000<$ taraf signifikansi $\alpha=0,05$, maka dapat disimpulkan bahwa ada pengaruh yang positif dan signifikan kontrol diri terhadap perilaku menabung siswa SMK se Kota Kediri. b). Variabel $\mathrm{X}_{2}$ pendidikan pengelolaan keuangan keluarga memiliki thitung $=3,441>1,971$ 
signifikansi $(\mathrm{sig})=0,007<$ taraf signifikansi $\alpha=0,05$ maka dapat disimpulkan bahwa ada pengaruh yang positif dan signifikan pendidikan pengelolaan keuangan keluarga terhadap perilaku menabung siswa SMK se Kota Kediri. c). Variabel $\mathrm{X}_{3}$ pengetahuan inklusi keuangan siswa memiliki thitung $=3.396>1,971$ signifikansi (sig) $=0.008<$ taraf signifikansi $\alpha=0,05$ maka dapat disimpulkan bahwa penegtahuan inklusi keuangan siswa terhadap perilaku menabung siswa SMK se Kota Kediri.

Tabel 2. Hasil Uji t

\begin{tabular}{|c|c|c|c|c|c|c|}
\hline \multirow{2}{*}{\multicolumn{2}{|c|}{ Model }} & \multicolumn{2}{|c|}{$\begin{array}{l}\text { Unstandardized } \\
\text { Coefficients }\end{array}$} & \multirow{2}{*}{\begin{tabular}{|c|}
$\begin{array}{c}\text { Standardized } \\
\text { Coefficients }\end{array}$ \\
Beta \\
\end{tabular}} & \multirow[b]{2}{*}{$\mathrm{t}$} & \multirow[b]{2}{*}{ Sig. } \\
\hline & & $B$ & Std. Error & & & \\
\hline \multirow[t]{4}{*}{1} & (Constant) & 22.891 & 1.448 & & 4.997 & .047 \\
\hline & Kontrol Diri & .592 & .028 & .897 & 21.496 & .000 \\
\hline & $\begin{array}{l}\text { Pendidikan Pengelolaan } \\
\text { Keuangan Keluarga }\end{array}$ & .866 & .251 & .742 & 3.441 & .007 \\
\hline & $\begin{array}{l}\text { Pengetahuan Inklusi } \\
\text { Keuangan Siswa }\end{array}$ & .525 & .164 & .536 & 3.396 & .008 \\
\hline
\end{tabular}

Sumber : data diolah, (2015)

Uji F statistik digunakan untuk mengetahui ada tidaknya pengaruh secara bersama-sama variabel bebas terhadap variabel terikat. Untuk mengetahui adanya pengaruh secara simultan ketiga variabel bebas terhadap variabel terikat dapat dilakukan dengan cara membandingkan hasil $F_{\text {hitung }}$ dengan $F_{\text {tabel }}$ dan juga bisa melalui perbandingan probabilitas value (sig). Jika sig $<0,05$ maka Ha diterima dan jika sig $>0,05$ maka Ha ditolak. Adapun hasil uji F adalah sebagai berikut:

Tabel 3. Hasil Uji F

\begin{tabular}{|c|c|c|c|c|c|c|}
\hline \multicolumn{2}{|c|}{ Model } & Sum of Squares & Df & Mean Square & $\mathrm{F}$ & Sig. \\
\hline \multirow[t]{3}{*}{1} & Regression & 2824.759 & 3 & 941.586 & 400.609 & $.000^{\mathrm{a}}$ \\
\hline & Residual & 486.530 & 207 & 2.350 & & \\
\hline & Total & 3311.289 & 210 & & & \\
\hline
\end{tabular}

Sumber : data diolah, (2015)

Berdasarkan tabel 4.13 dapat diamati bahwa $F_{h i t u n g}=400.609$, sedangkan $F_{\text {tabel }}$ dengan df1:2, dan df2:129 $=2.648$ dan probabilitas value (sig) dalam penelitian ini $=0,000<0,05$ dengan demikian $\mathrm{H}_{0}$ ditolak dan Ha diterima, sehingga dapat disimpulkan bahwa secara simultan (bersama-sama) variabel bebas perilaku menabung, pendidikan pengelolaan keuangan keluarga dan pengetahuan inklusi keuangan berpengaruh signifikan terhadap perilaku menabung siswa SMK se Kota Kediri. Nilai positif pada variabel ini menunjukkan bahwa kontrol diri, pendidikan pengelolaan keuangan keluarga, dan pengetahuan inklusi keuangan siswa memiliki hubungan yang searah dengan perilaku menabung siswa SMK se Kota Kediri, yang bermakna semakin tinggi kontrol diri, 
pendidikan pengelolaan keuangan keluarga dan pengetahuan inklusi keuangan siswa, maka semakin tinggi pula perilaku menabung siswa SMK se Kota Kediri.

Berarti H0 ditolak dan Ha diterima. Besarnya pengaruh kontrol diri, pendidikan pengelolaan keuangan keluarga, pengetahuan inklusi keuangan siswa secara simultan terhadap perilaku menabung siswa dapat dilihat dari Adjusten Rsquare yaitu:

Tabel 4. Koefisien Determinasi

\begin{tabular}{|l|r|r|r|c|}
\hline Model & $\mathrm{R}$ & $\mathrm{R}$ Square & \multicolumn{1}{c|}{$\begin{array}{c}\text { Adjusted R } \\
\text { Square }\end{array}$} & $\begin{array}{c}\text { Std. Error of the } \\
\text { Estimate }\end{array}$ \\
\hline 1 & $.924^{\mathrm{a}}$ & .853 & .851 & 1.533 \\
\hline
\end{tabular}

Sumber: Data diolah, (2015)

Nilai adjusted R-square yang dihasilkan sebesar 0.853 menunjukkan bahwa perilaku menabung dipengaruhi kontrol diri, pendidikan pengelolaan keuangan keluarga, pengetahuan inklusi keuangan siswa sebesar 85,3 \% sedangkan 14,7\% dipengaruhi oleh variabel-variabel lain yang tidak diteliti.

Uji Hipotesis: untuk mengetahui hipotesis yang diajukan penulis terjawab atau tidak dalam penelitian ini maka berdasarkan hasil pengolahan data diatas disimpulkan sebagai berikut:

a) Hipotesis ke-1 "diduga kontrol diri berpengaruh terhadap perilaku menabung siswa SMK se Kota Kediri." Hipotesis ke-1 terjawab dari hasil nilai t-hitung sebesar 21,496 dengan tingkat signifikan kurang dari 5\% yaitu 0,000 pada kontrol diri. Hal ini berarti bahwa kontrol diri secara parsial berpengaruh signifikan positif terhadap perilaku menabung siswa SMK se Kota Kediri sehingga hipotesis ke-1 penelitian ini diterima.

b) Hipotesis 2 "diduga pendidikan pengelolaan keuangan keluarga terhadap perilaku menabung siswa." Hipotesis ke-2 terjawab dari hasil nilai t-hitung sebesar 3,441dengan tingkat signifikan kurang dari 5\% yaitu 0,007 pada variabel pendidikan pengelolaan keuangan keluarga. Hal ini berarti bahwa pendidikan pengelolaan keuangan keluarga secara parsial berpengaruh signifikan positif terhadap perilaku menabung siswa SMK se Kota Kediri, hipotesis ke 2 penelitian ini diterima.

c) Hipotesis ke 3 "diduga pengetahuan inklusi keuangan siswa berpengaruh terhadap perilaku menabung siswa SMK se Kota Kediri." Hipotesis ke 3 terjawab dari hasil nilai t hitung sebesar 3.396 dengan nilai signifikan kurang dari 5\% yaitu 0,008. Maka dapat disimpulkan bahwa pengetahuan inklusi keuangan siswa berpengaruh signifikan positif terhadap perilaku menabung siswa SMK Se Kota Kediri, sehingga hipotesis ke-3 penelitian ini diterima.

d) Hipotesis ke 4 "diduga kontrol diri, pendidikan pengelolaan keuangan keluarga, dan pengetahuan inklusi keuangan siswa secara bersama-sama berpengaruh terhadap perilaku menabung siswa SMK se Kota Kediri." Hipotesis ke 4 terjawab dari hasil nilai $F_{\text {hitung }}$ sebesar 400.609 dengan nilai signifikan kurang dari 5\% yaitu 0,000. Maka dapat disimpulkan bahwa kontrol diri, pendidikan pengelolaan keuangan keluarga, pengetahuan inklusi 
keuangan siswa berpengaruh secara simultan terhadap perilaku menabung siswa SMK se Kota Kediri, sehingga hipotesis ke-3 penelitian ini diterima.

Kesimpulan yang diperoleh dari analisis data dengan menggunakan SPSS 22 yakni variabel kontrol diri berpengaruh terhadap perilaku menabung siswa SMK se Kota Kediri. Hal ini memberikan makna bahwa kontrol diri dan perilaku menabung memiliki hubungan yang searah. Semakin tinggi atau positif kontrol diri maka seiring dengan meningkatnya perilaku menabung siswa. Sebaliknya apabila semakin rendah atau negatif kontrol diri seseorang maka semakin rendah pula perilaku menabung siswa.

Penelitian ini sejalan dengan pendapat Otto (2004) yang mengemukakan bahwa setiap pengelolaan keuangan yang baik menuntut pola hidup yang memiliki prioritas dan kemampuan self control yang baik. Pada dasarnya kekuatan dari prioritas (the power of priority) berpengaruh juga terhadap tingkat kedisiplinan seseorang ketika mengelola keuangannya, salah satunya dalam kegiatan menabung maupun investasi.

Penelitian lain dikemukakan oleh Nofsinger (2005) yang menyatakan bahwa kemampuan seseorang dalam mengontrol diri dengan melawan keinginan untuk membelanjakan uang secara berlebihan, dengan kata lain mampu membelanjakan sesuai dengan kebutuhan bukan keinginan. Dengan demikian self control salah satu faktor yang digunakan oleh individu untuk mencegah pemborosan sehingga dapat mengalokasikan uang untuk tabungan jangka panjang. Lebih lanjut Sumaryono (2013) yang menyatakan bahwa kurangnya kontrol diri yang dimiliki remaja memicu munculnya perilaku pembelian yang impulsive, salah satu faktor yang menyebabkan kontrol diri rendah yakni perilaku ikut-ikutan yang terjadi pada remaja saat ini. Perilaku konsumtif yang seperti ini dapat dihindari oleh remaja jika memiliki sitem pengendalian diri yang baik, tidak mudah terpengaruh oleh teman sebaya, memanage uang saku yang diberikan orang tua, memprioritaskan tabungan, dan pembiasaan berbelanja sesuai dengan kebutuhan Sipunga (2014).

Dari pembahasan di atas dapat disimpulkan bahwa hipotesis yang menyatakan bahwa diduga ada pengaruh kontrol diri terhadap perilaku menabung siswa SMK se Kota Kediri dapat diterima. Berdasarkan analisis data, diperoleh hasil secara parsial pendidikan pengelolaan keuangan keluarga berpengaruh positif terhadap perilaku menabung siswa SMK se Kota Kediri. Hal ini menunjukkan bahwa semakin baik orang tua memberikan pendidikan pengelolaan keuangan pada anak maka semakin baik anak dalam mengelola keuangan khususnya dalam menyisihkan uang untuk ditabung. Begitupun sebaliknya, semakin baik orang tua dalam memberikan pendidikan pengelolaan keuangan kepada anak maka semakin baik perilaku menabung siswa.

Hasil ini sejalan dengan penelitian yang dilakukan Sulaeman (2012) orang tua merupakan sumber yang paling penting dari pengetahuan tentang pengelolaan pribadi keuangan anak, yang berarti orang tua harus memberikan contoh kepada anak dalam mengelola keuangan pribadi. Oleh karena itu orang tua harus aktif memberikan pendidikan keuangan kepada anak mereka dan harus memahai dan memberikan pemahaman terhadap perkembangan produk dan jasa keuangan.

Diperkuat oleh Penelitian Lusardi et all (2010) menjelaskan orang tua memberikan peran dalam melakukan proses pembelajaran keuangan kepada anak. 
Siswa yang orang tuanya memiliki pengetahuan keuangan yang baik akan lebih paham bagaimana mengelola keuangan dengan baik pula.

Dalam upaya mengembangkan pribadi anak, keluarga turut mengambil peranan yang sangat penting sebagai seorang pendidik dan orang yang paling bertanggung jawab di lingkungan keluarga dalam mendidik anak-anaknya. Mulai dari sikap, tutur kata, tingkah laku, dan nilai-nilai yang ditanamkan orang tua pada anak merupakan landasan utama bagi perkembangan anak tingkah laku selanjutnya.

Memberikan uang saku kepada anak menunjukkan kepercayaan orang tua kepada anak. Memberikan uang saku kepada anak melatih tanggung jawab finansial untuk mengatur keuangan mereka sendiri seperti membelanjakan dan menabung. Dengan memberikan pendidikan pengelolaan keuangan maka ada beberapa hal yang positif terkait dengan membelanjakan, menabung, maupun mengivestasikan uang dengan benar lermitte (dalam Susanti, 2013).

Hasil penelitian ini juga searah dengan penelitian Salikin dkk pada tahun 2012 bahwa orang tua berpengaruh terhadap perilaku menabung mahasiswa. Perilaku menabung mahasiswa bergantung pada status sosial ekonomi orang tua maupun pendidikan pengelolaan keuangan yang diberikan oleh keluarga. Berdasarkan teori dan bukti empiris di atas, maka dapat diambil suatu hubungan bahwa pendidikan pengelolaan keuangan keluarga memiliki pengaruh terhadap perlaku menabung siswa.

Hasil penelitian ini menunjukkan bahwa pengetahuan inklusi keuangan siswa memiliki pengaruh yang positif terhadap perilaku menabung siswa SMK se Kota Kediri. Sehingga dapat diartikan bahwa semakin baik pengetahuan siswa tentang inklusi keuangan maka semakin baik perilaku menabung siswa SMK se Kota Kediri.

Penelitian yang dilakukan oleh Brief (2012) menyimpulkan bahwa sekolah dan lembaga keuangan merupakan mitra atau partner dalam menumbuhkan kebiasaan anak dalam menabung. Pengetahuan inklusi keuangan dan pengalaman sejak dini tentang perbankan dapat membantu anak membangun kebiasaan keuangan yang baik, melatih kontrol diri dan memiliki rencana masa depan.

Penelitian lain yang dilakukan oleh East African Communityy (2014) menunjukkan bahwa lembaga keuangan dapat meningkatkan akses masyarakat agar bank able dengan mengandalkan karakteristik sosial ekonomi, selain itu juga harus meningkatkan pengetahuan produk-produk bank dan layanan perbankan di sekolah dan perguruan tinggi. Dengan kata lain dapat disimpulkan seseorang dikatakan perilaku menabung akan baik apabila pengetahuan inklusi keuangan yang baik sehingga faham dengan produk-produk perbankan dan pemanfaatannya.

Selaras dengan penelitian ini, Lyons et al (2006) bahwa kemampuan menabung anak dipengarughi oleh sosial ekonomi, program pembelajaran di sekolah dan pengetahuan anak tentang perbankan. Sedangkan penelitian yang dilakukan Sherraden (2008), menyatakan kesadaran anak membuka rekening tabungan dipengaruhi pembiasaan menabung siswa orang tua, akan tetapi pengetahuan keuangan anak tidak berpengaruh. Berdasarkan bukti empiris di atas, maka dapat diambil suatu hubungan bahwa pengetahuan inklusi keuangan siswa memiliki pengaruh terhadap perlaku menabung siswa.

Berdasarkan analisis data yang telah dilakukan, diperoleh hasil bahwa kontrol diri, pendidikan pengelolaan keuangan keluarga dan pengetahuan inklusi 
keuangan siswa secara simultan berpengaruh terhadap perilaku menabung siswa SMK se Kota Kediri. Pernyataan tersebut berdasarkan dari hasil uji F dimana nilai signifikansi sebesar $0,000<0,05$. Hal ini menunjukkan bahwa variabel independen berpengaruh signifikan dengan variabel dependen. Berdasarkan analisis data didapatkan hasil yang menunjukkan bahwa kontrol diri, pendidikan pengelolaan keuangan keluarga dan pengetahuan inklusi keuangan siswa secara simultan berpengaruh terhadap perilaku menabung siswa SMK se Kota Kediri memiliki koefisien determinasi sebesar 0,853. Hasil tersebut memberikan makna perilaku menabung dipengaruhi oleh kontrol diri, pendidikan pengelolaan keuangan keluarga, dan pengetahuan inklusi keuangan siswa sebesar 85,3\% sedangkan sebesar $14,7 \%$ dipengaruhi oleh faktor-faktor lain yang tidak diteliti.

Hasil penelitian ini merujuk pada penelitian yang dilakukan oleh Thung dkk (2012) yang menunjukkan bahwa perilaku menabung mahasiswa di Malaysia dipengaruhi secara signifikan oleh beberapa faktor yakni financial literacy, pola pendidikan pengelolaan keuangan keluarga, kelompok teman sebaya dan kontrol diri. Penelitian lain yang dilakukan oleh Brief (2012) menyimpulkan bahwa penegtahuan inklusi keuangan dan pengalaman sejak dini tentang perbankan dapat membantu anak membangun kebiasaan keuangan yang salah satunya kebiasaan menabung dan melatih kontrol diri serta memiliki rencana masa depan. Dengan demikian, hipotesis yang menyatakan bahwa ada pengaruh kontrol diri, pendidikan pengelolaan keuangan keluarga, pengetahuan inklusi keuangan siswa, berpengaruh terhadap perilaku menabung diterima.

\section{SIMPULAN}

Berdasarkan hasil analisis yang telah dibahas, dapat ditarik kesimpulan sebagai berikut: 1.) Terdapat pengaruh kontrol diri terhadap perilaku menabung siswa di SMK N 2 Kediri. Hal ini berarti variabel kontrol diri secara parsial berpengaruh signifikan dan positif terhadap perilaku menabung siswa SMK se Kota Kediri. Sehingga semakin tinggi kontrol diri siswa berpengaruh terhadap tingginya perilaku menabung siswa. Artinya jika siswa memiliki kontrol diri yang tinggi dalam membelajakan uang sakunya maka perilaku menabung siswa SMK se Kota Kediri cukup tinggi pula. Demikian sebaliknya jika siswa memiliki kontrol diri yang rendah dalam membelanjakan uang sakunya maka perilaku menabung siswa SMK se Kota Kediri akan rendah. Hasil temuan pada penelitian ini membuktikan bahwa perilaku menabung lebih didukung oleh kontrol kognitif dan kontrol keputusan.

Meskipun aspek kontrol perilaku masih kurang, akan tetapi siswa sudah dapat mempertimbangkan hal positif dan negatif akibat perilaku konsumsi mereka; 2.) Terdapat pengaruh pendidikan pengelolaan keuangan keluarga terhadap perilaku menabung siswa. Hal ini berarti pendidikan pengelolaan keuangan keluarga secara parsial berpengaruh secara signifikan dan positif terhadap perilaku menabung siswa SMK se Kota Kediri. Artinya bahwa tinggi atau rendahnya pendidikan pengelolaan keuangan di keluarga berpengaruh terhadap perilaku menabung siswa SMK se Kota Kediri. Apabila orang tua memiliki pengetahuan pengelolaan keuangan yang tinggi, perhatian akan keuangan anak cukup intens maka perilaku menabung siswa SMK se Kota Kediri akan cukup tinggi. Hasil temuan dari penelitian ini lebih didukung oleh indikator 
pembiasaan menabung yang dilakukan oleh orang tua. Perilaku menabung siswa akan lebih baik apabila didukung oleh lingkungan keluarga yang senantiasa melatih dan memberikan teladan dalam kegiatan menabung; 3.) Terdapat pengaruh pengetahuan inklusi keuangann siswa terhadap perilaku menabung siswa. Artinya pengetahuan inklusi keuangan secara parsial berpengaruh signifikan dan positif terhadap perilaku menabung siswa SMK se Kota Kediri. Artinya bahwa tinggi atau rendahnya pengetahuan inklusi keuangan siswa berpengaruh terhadap perilaku menabung siswa SMK se Kota Kediri. Apabila pengetahuan siswa mengenai produk-produk perbankan maka semakin tinggi pula perilaku menabung siswa SMK se Kota Kediri. Hasil temuan pada penelitian ini menunjukkan semakin baik pengetahuan siswa mengenai produk perbankan, maka akan semakin termotivasi dalam aktivitas menabung; 4.) Pengaruh kontrol diri, pendidikan pengelolaan keuangan keluarga, pengetahuan inklusi keuangan siswa terhadap perilaku menabung siswa SMK se Kota Kediri adalah signifikan. Hal ini menggambarkan bahwa ketiga variabel bebas tersebut memiliki peran membentuk perilaku menabung siswa SMK se Kota Kediri.

\section{DAFTAR RUJUKAN}

Averil, James. 1973. Personal Control Over Aversive Stimuli and Its Relationship to Stress. Psycology Bulletin, Vol. 80 No. 4, (PP: 286-303).

Brief. 2012. Youth Financial Inclusion : Complementing Financial Education with Account Access. Journal for financial security, Vol. 5 No. 1, (PP: 1-4).

East African Comunity. 2014. Determinants Of Household Savings Mobilization Across EAC Countries : An Explanatory Analysis. International Paper East African Comunity, (PP: 1-24).

Firmansyah, Danny. 2014. The Influence of Family Backgrounds Toward Student Saving Behavior: A Survey of College Students in Jabodetabek. International Journal of Scientific and Research Publication, Vol. 4. No. 1, (PP: 1-6).

Ghufron, M.N. 2010. Teori-Teori Psikologi. Jogjakarta: Ar - Ruz Media

Hoyri, Imam. 2014. Kontrol Diri dan Perilaku Konsumtif Pada Siswa SMA, Ditinjau dari Lokasi Sekolah. Jurnal Online Psikologi, Vol. 02, No. 01, (PP: 1-12).

Keynes, J.M. 1935. The General Theory of Employment, Interest and Money. New York: Macmilan ST Martins Press.

Lusardi, A. Olivia S. Mitchell and Vilsa Curto. 2010. Financial Literacy Among

TheYoung. Journal of Concumer Affair, Vol. 44, No. 2, (PP: 358-380).

Lyons, A.C., Lance Palmer, and Erik Scherpf. 2006. Are We Making the Grade?

A Nation Overviews of Financial Inclusion Education and Program Evaluation. Journal of Consumer Affair, Vol. 4, No. 2, (PP: 200-235).

Nababan, Darman. 2011. Analisa personal financial literacy dan financial behavior mahasiswa SI Fakultas Ekonomi Universitas Sumatera Utara. Sumatera Utara: Universitas Sumatera Utara.

Nofsinger, J.R. 2005. Social Mood and Financial Economics. Journal of Behavioral Finance, Vol. 6. No. 3, (PP: 144-160). 
Nurasiyah.A. 2010. Analisis Pengaruh Lingkungan Sosial Ekonomi Terhadap Perilaku Konsumtif Siswa (Studi Kasus pada SMA se Kota Bandung). Jurnal Sains dan Terapan, Vol. 5, No. 1, (PP:4-15).

Otto Philip E, \& Nick Charte Greg B Davies. 2004. Note on ways of saving: mental mechanism as tools for self control?. Global Business and Economics Review, (PP: 227-257).

Owen, D. 2003. Melejitkan Kecerdasan Financial Anak, Terjemahan Lovely. Bandung: Kaifa

Salikin, Nurul Huda, S Wahab, N.A, Masruki, R. Zakaria. 2012. The Influence of Parents Bacground ob Students Svings. International Proceeding of Economics Development and Research, (PP: 1- 6).

Sherraden, M.S. 2008. Financial Capability: What is it, and how Can it be Created. CSD: St Washington University Center for Social Development.

Sipunga, Nilawati. 2014. Kecenderungan Perilaku Konsumtif Remaja di Tinjau dari Pendapatan Orang Tua pada Siswa-siswi SMA Ksatrian 2 Semarang, Journal of Social and Industrial Psychologi, Vol. 3 No. 1, (PP:1-7).

Sulaeman, D. Humalik. 2012. Psikologi Remaja Dimensi-Dimensi Perkembangan. Bandung : CV. Mandar Maju.

Sumaryono, H. 2013. Pembelian Impulsive Ditinjau dari Kontrol Diri dan Jenis Kelamin. Jurnal Psikologi Proyeksi, Vol. 3, No. 1, (PP: 2-46).

Susanti. 2013. Faktor-faktor Yang Mempengaruhi Literasi Keuangan Mahasiswa Fakultas Ekonomi Universitas Negeri Surabaya, Jurnal Ekobis, Vol. 18, No. 1, (PP: 1-15).

Thung, Chai Ming, Chia Ying Kai, \& Fong Sheng Nie. 2012. Determinants of Saving Behavior Among The University Students In Malaysia. RMP TIG3 Conferences, (PP: 15-126).

Wahid, Nusron. 2014. Keuangan Inklusif : Membangun Hegemoni Keuangan. Jakarta: Gramedia.

Wahyono, H. 2001. Pengaruh Perilaku Ekonomi Kepala Keluarga terhadap Intensitas Pendidikan Ekonomi di Lingkungan Keluarga. (Disertasi, Doktor Pendidikan Ekonomi tidak dipublikasikan. Universitas Negeri Malang. 